\title{
6
}

\section{In Between Presence and Absence: Ambiguous Encounters of the State in Unconventional Gas Developments in Queensland, Australia}

\author{
Martin Espig
}

\section{Introduction}

Australia's natural gas industry has grown rapidly over the last two decades. Sourced from conventional and unconventional resources, a majority of this new capacity is supplying a liquefied natural gas industry that exports to overseas energy markets. In the country's northeastern state of Queensland, the extraction of gas located within the cleats of underground coal seams has become technologically and economically viable since the turn of the millennium. This unconventional coal seam gas (also called coal bed methane) is not contained within pressurised reservoirs like conventional oil and gas but dispersed throughout coalbearing strata of large geological basins. Accessing coal seam gas (CSG) therefore requires numerous wells to be drilled in close grids across broad areas (see Figure 6.1). Groundwater is removed to lower the hydrostatic pressure that holds the gas in place, and both then flow to the surface where they are separated. Although less than in other unconventional 
gas sources, this process also includes controversial extraction techniques such as hydraulic fracturing ('fracking'). Following the industry's swift growth and over AUD70 billion invested over the last decade and a half, around 11,000 producing CSG wells are currently operational across Queensland. The total number of wells is expected to double once the industry is fully established. The processing and transport of gas and water involve additional infrastructure such as gathering pipelines, well pad access tracks, compressor stations and water treatment facilities.

Establishing these extractive networks and accounting for the various impacts of their collective footprint has so far resulted in some 5,700 Conduct and Compensation Agreements negotiated between gas companies and landholders (GCQ 2018). However, CSG developments and associated regional transformations have not occurred without disputes over potential risks associated with the dynamically evolving industry (de Rijke 2013a: 46-8; Espig 2018: 11). Particularly salient points of contestation within host communities and among the wider public revolved around impacts to groundwater and negative health effects for those living in proximity to CSG infrastructure. These debates were exacerbated by perceived absences in state regulatory and oversight function and the fact that, considering the pace and complexity of the industry's developments, many decisions involved scientific uncertainties regarding its short and long-term impacts.

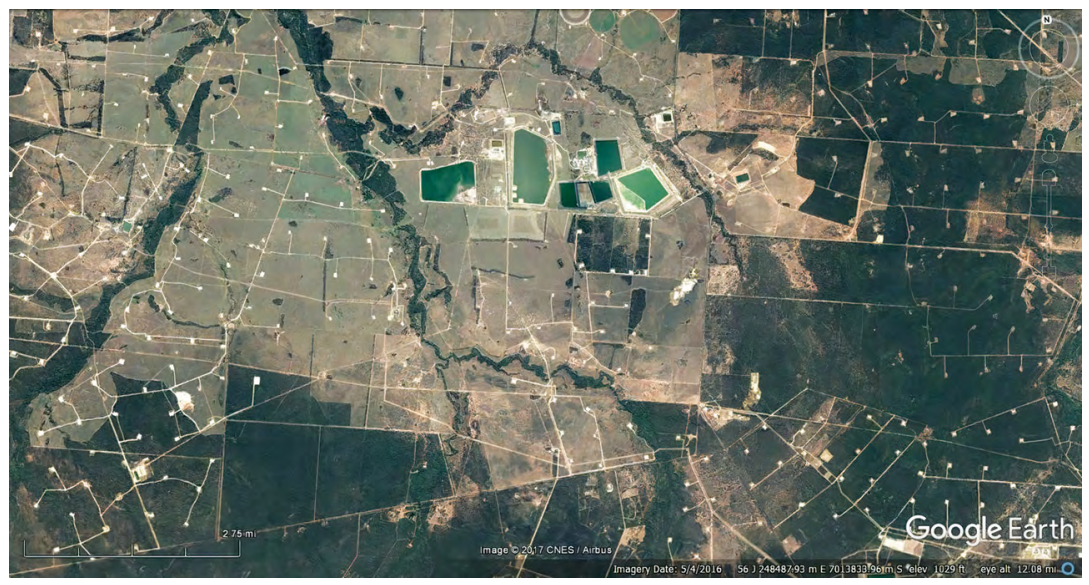

Figure 6.1 A coal seam gas field in the Western Downs region

Source: Google Earth 2020 


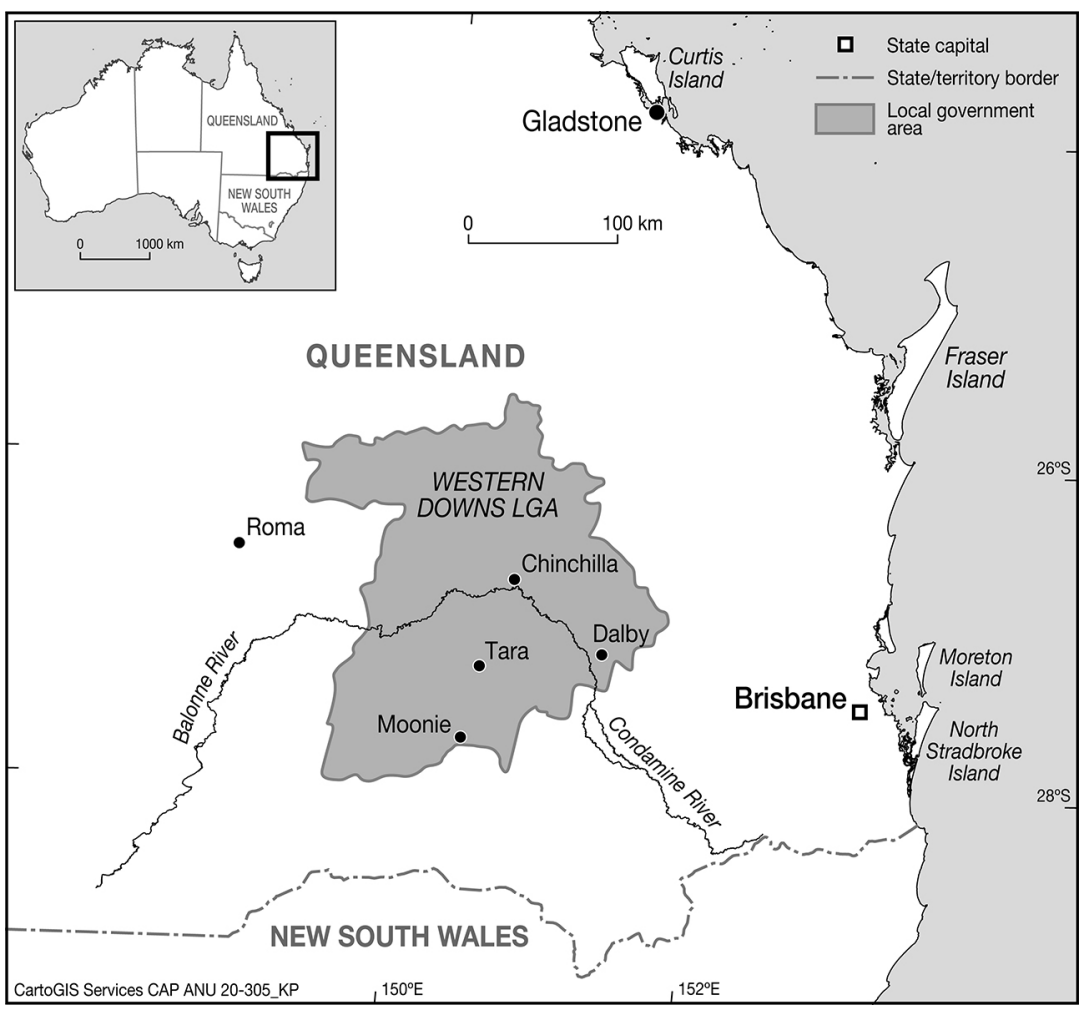

Figure 6.2 The Western Downs local government area and Curtis Island, the location of LNG processing and export facilities some $500 \mathbf{~ k m}$ to the north

Source: ANU Cartography

This chapter focuses on the risk controversy surrounding CSG developments in Queensland and how they pertain to the role of the state in natural resource developments. My analysis draws on research of CSGrelated topics since 2011, including multi-sited ethnographic fieldwork conducted between late 2014 and 2016 in one of the CSG hotspots in Queensland, the Western Downs local government area (see Figure 6.2). This predominantly agricultural region covers a land area of almost $38,000 \mathrm{~km}^{2}$ and is home to some 33,000 people. With thousands of operational wells, the Western Downs is the most intensively developed area in Australia in terms of unconventional gas projects. Its gas fields supply three major liquefied natural gas (LNG) plants that are located some $500 \mathrm{~km}$ to the north on Curtis Island near the town of Gladstone (Eriksen 2018). 
Many irrigating farmers and graziers in the Western Downs, who rely on historically already overused aquifers, voiced concerns about uncertainties regarding the quantity of groundwater extracted over the CSG industry's multiple decades-long lifespan. Especially early on, these concerns were well-founded, as levels of uncertainty were high even among scientific researchers, industry professionals and regulators (Espig and de Rijke 2016). Debates also emerged around the potential impacts of chemicals used during extraction. Some residents were further opposed to possible human health risks from environmental pollution associated with, for instance, leaking wells and infrastructure, which prompted them to emphasise potentially unknown side effects of CSG extraction and perceived shortcomings in state departments' regulatory oversight. In this sense, uncertainties not only existed around the scientific aspects of CSG developments and potential environmental impacts. For many concerned residents, uncertainties also manifested in a normative sense regarding the roles of state departments and their regulatory capacities, as well as in moral terms concerning the trustworthiness of state and CSG industry actors. This chapter is developed around interlocutors' accounts regarding these aspects.

While my research also involved Queensland state politicians, regulators and urban-based scientists, the chapter is primarily based on ethnographic work with rural landholders and regional residents in the Western Downs. Among those community members, only small minorities either unequivocally supported or outright opposed CSG developments. I more often encountered mixed feelings towards the industry, with many interlocutors describing positive as well as negative aspects of CSG projects. This is in line with surveys conducted at the time of my fieldwork, which show that a majority of participating Western Downs residents either tolerated or accepted the CSG industry (Espig 2018: 160-6). In this chapter, I focus specifically on interlocutors who expressed concerns over CSG projects' risks and uncertainties, regardless of their overall attitude towards the industry. ${ }^{1}$ Those interlocutors dealt with a variety of Queensland state departments, including the Department of Natural Resources, Mines and Energy and the Department of Environment and Heritage Protection, as well as associated entities such as the Office of

1 By focusing on one segment of my ethnographic data, I do not intend to oversimplify community members' differences nor to 'sanitise' the local politics of representation and conflict (Trigger 2000: 203; Ballard and Banks 2003: 306; see Espig and de Rijke 2018 for a corresponding discussion). For a relevant debate on the 'problem of ethnographic refusal' (Ortner 1995) in the context of mining, see Bainton and Owen (2018) and Kirsch (2018: 9-12 and 28-9). 
Groundwater Impact Assessment or GasFields Commission Queensland. It would therefore be misleading to regard the Queensland state as a single monolithic entity and community members' encounters with the state as uniform. The following account should be read accordingly.

Through the lens of CSG risk debates, it is possible to understand community members' experiences of the state within natural resource developments, especially the ambiguous encounters and frictions that projects can create between the state and concerned members of host communities. My primary intention behind developing this perspective is not to analyse the Queensland state as a government apparatus of specific institutions, regulatory instruments and bureaucratic procedures. Instead, I follow Sharma and Gupta (2005: 27) in regarding states 'as culturally embedded and discursively constructed ensembles', and Trouillot (2003: 89) in presenting the state as 'a set of practices and processes and the effects they produce'. My aim is to contribute towards an anthropological understanding of 'how states are culturally constituted, how they are substantiated in people's lives, and ... the sociopolitical and everyday consequences of these constructions', which makes it necessary to focus on 'everyday practices and representations as modes through which the state comes into being' (Sharma and Gupta 2005: 27). Rather than attending to its mere institutional contours, I focus on the communitystate interface and examine how concerned host community members encountered 'the state' in CSG risk debates. ${ }^{2}$

The following section briefly describes the regulatory foundations of CSG developments and highlights the Queensland state's presence in terms of granting and guaranteeing land access rights. I outline residents' reactions to this presence, and how the Queensland state's risk governance policies account for uncertainties. The two subsequent sections paint a contrasting picture of a partially absent state, with CSG projects outpacing regulating departments in some cases and pushing them beyond their capacity, especially once developments fully commenced. Concomitantly, concerned members of affected communities and the wider public struggled to receive clear answers while navigating what I described as the resulting organised irresponsibility around CSG developments. This leads to a discussion on the displacement, or delegation, of state functions and a responsibilisation of community members. Exploring the

2 See Bainton and Skrzypek (Chapter 1, this volume) for a corresponding discussion of Philip Abrams' distinction between the 'state-system' and the 'state-idea'. 
theme of 'absent presence', I argue that a dialectic of state presence and absence reconfigures the relationships between the Queensland state, its subjects, and multinational gas companies. In these relational contexts, gas companies cannot merely rely on the state for their operational and 'social licence'. Conversely, material presented here also demonstrates that a privatisation of risk emerged around CSG developments, which can create significant uncertainties and (re)produce social inequalities among members of host communities. The ambiguous encounters of actors in the spaces in between state presence and absence thus produce a set of interwoven sociocultural and political challenges. The chapter concludes with a critical question regarding the responsibility and accountability of the various actors involved in contemporary resource developments.

\section{The State within CSG Risk Debates}

Australia has an identified 257 trillion cubic feet of conventional and unconventional natural gas resources, of which CSG accounts for about one third (AFG 2018). The legal and regulatory framework for the oil and gas sector is broadly divided into onshore and offshore activities. Under Australian law, ownership of onshore gas resources is vested in the Crown, namely the states or Commonwealth. This means that exploration and production titles are granted by respective state and federal governments (Hepburn 2015). ${ }^{3}$ Throughout this chapter, I therefore refer to the institutional, legal and regulatory aspects of the Queensland State and, to a lesser extent, the Western Downs local government when discussing 'the state'. One of the main legal instruments regulating the CSG industry's activities is the Petroleum and Gas (Production and Safety) Act 2004 (Queensland). ${ }^{4}$ The Act's main purpose is, among others:

to facilitate and regulate the carrying out of responsible petroleum activities and the development of a safe, efficient and viable petroleum and fuel gas industry, in a way that (a) manages the State's petroleum resources (i) in a way that has regard to the need for ecologically sustainable development; and (ii) for the benefit of all Queenslanders; and ... (c) creates an effective and efficient regulatory system for the carrying out of petroleum activities and

\footnotetext{
3 See QSG (2020: 62) for a process map that details the responsibilities and entities throughout the coal seam gas process, from tendering, exploring, producing to decommissioning.

4 See www.legislation.qld.gov.au/view/pdf/current/act-2004-025
} 
the use of petroleum and fuel gas; and ... (f) ensures petroleum activities are carried on in a way that minimises conflict with other land uses.

Two important notions, which are commonly found in similar regulatory instruments, are that publicly owned natural resources are to be developed for the 'greater good' and that the state assumes the entrusted responsibility to regulate these developments on behalf of its citizens, including those with interests in other land uses (Hepburn 2015; Taylor and Hunter 2019; also Bainton and Skrzypek, Chapter 1, this volume). For landholders in the Western Downs, as in most other jurisdictions around the world, this means that subterranean hydrocarbon resources underneath their properties are the domain of the state and not of their private ownership.

More than any other Australian state, Queensland has followed a prodevelopment agenda in support of the CSG industry (Cronshaw and Quentin Grafton 2016; Espig 2018: 79-84 and 206-7). With resource extraction being part of a wider Australian 'culture of development ideology' (Trigger 1997; also Cleary 2011) and a 'growth-first' political economy (Mercer et al. 2014), the prospect of substantial CSG project investments was embraced by successive Queensland governments. As some observers have argued, this included approaching uncertainties over environmental impacts and risk concerns through 'an attitude of "technological optimism" ... a confidence that the engineers and geologists (and markets) will solve whatever disposal or environmental problems arise' (Edwards 2006: 97). With resource ownership vested in the Queensland state, landholders had limited authority over whether and how CSG reserves were developed.

Gas companies that have been granted exploration or production titles are within their rights to demand access to private properties and can request the state to enforce this right, subject to a number of legally prescribed procedures and compensation provisions. For example, access disputes can be referred to the Queensland Land Court that specifically deals with matters relating to land and resources. For some landholders, encounters with the state in the context of CSG developments resemble Ballard and Banks' (2003: 299) observation of the mining sector:

Disputes over access to and ownership of mineral resources have generated protracted confrontations between the legal apparatus of the state and the precepts of local communities, many of which first encounter the full power of the state's sovereign claims to resources only through this process of dispute. 


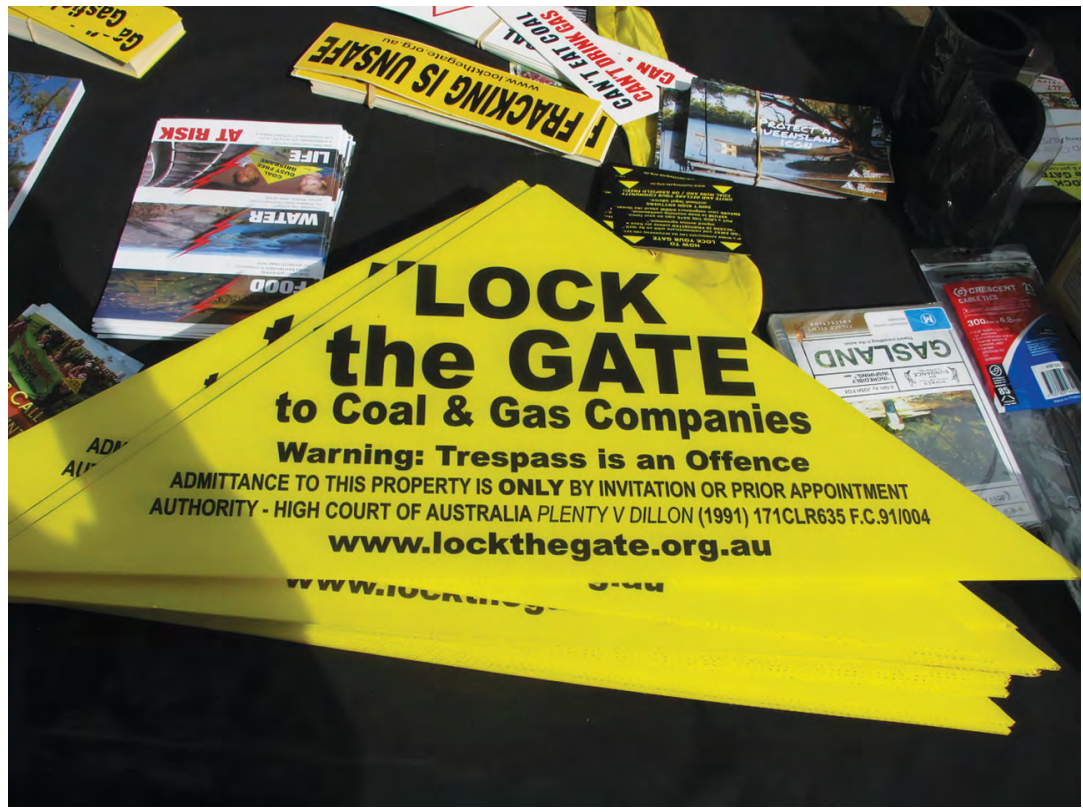

Figure 6.3 Lock the Gate Alliance paraphernalia at a demonstration in Brisbane, Australia, 2015

Source: Photograph by author

While only a relatively small number of cases actually proceeded to Land Court, the mere possibility already asserted enough coercive force in many instances. Acknowledging companies' state-guaranteed rights, several landholders who negotiated access, primarily through Conduct and Compensation Agreements, likened the process to a 'shotgun wedding' rather than voluntary negotiations. As the facilitator of the industry, the state is, in this sense, all too present for regional landholders, whether its sovereign powers are actually enforced or not (see also Holcombe, Chapter 7; and Lewis, Chapter 8, both this volume). ${ }^{5}$

Other members of host communities and the wider Australian public have instead chosen to resist and challenge gas companies and the state. The Lock the Gate Alliance, for instance, is an organisation that promotes a path of civil disobedience by advising landholders to refuse gas and mining companies access to their properties. They provide warning signs

5 Notions of coexistence with agricultural land uses or the industry's social licence to operatepredominantly invoked by staff in CSG companies and some state departments - might therefore first and foremost be about successful land access rather than the establishment of mutually beneficial relationships (Owen and Kemp 2017: 24). 
that can be attached to gates and fences, bright yellow triangles that are well known in some parts of Australia-although less so in the Western Downs (see Figure 6.3). The alliance and associated individuals also make regular submissions to CSG and mining-related government bills and appear in regional and national media. Lock the Gate initially formed in the Western Downs with the first wave of opposition to local CSG developments. Since then, key protagonists have left the region and the alliance has shifted its focus and head office into the adjacent state of New South Wales, where proposed CSG projects are still at exploration and planning stages. According to some alliance members, part of this transition has been due to the industry progressing too rapidly in Queensland. This meant that organised resistance only formed once projects were in full development and many landholders had already entered into agreements. However, Makki (2015) investigated the identity politics within the Western Downs and put forward an alternative explanation. He noted that the perceived 'protester' identities of alliance members and associated community groups was incompatible with the predominantly conservative agrarian identities of the region's other residents (also Makki and van Vuuren 2016). Throughout my ethnographic research, I similarly observed that residents' critical engagements with CSG often occurred through forms of 'conforming resistance' instead of active protest; that is, by focusing on (scientific) evidence-making as a means of producing legitimate claims that can influence the decision making and regulation around CSG activities. This has, at least partly, been an attempt to avoid delegitimising 'protester' labels (Espig 2018: 196-204). These forms of resistance emerged in response to what was perceived as unacceptable uncertainties over CSG projects' various impacts. In turn, highlighting these uncertainties became an important aspect of their challenges of the state and gas companies.

Uncertainties are also an essential part of the 'adaptive management' regulatory regime applied to Queensland's CSG developments. This 'learning by doing' framework is a reaction to the pro-development ambitions of Queensland governments to establish a substantial gas export industry while pivotal questions regarding potential impacts were still uncertain. As Taylor and Hunter (2019: 51, footnote omitted) emphasise:

The dilemmas in creating effective petroleum regulation are the estimation of risks and benefits, which are often based on limited scientific knowledge, particularly in relation to hydraulic fracturing technology. Thus, the regulatory conundrum presents 
itself as follows, 'regulating too soon may stifle innovation, but regulating too late may result in significant or irreversible damage'. Such an approach is very much reactive, as the State responds to regulatory issues as they occur, rather than trying to anticipate and legislate for problems prior to the activity taking place. For example in Queensland, regulating unconventional gas activities 'too soon' has led to the search for a regulatory mechanism to manage coexistence.

Swayne (2012: 184) thus noted during the initial rush of CSG activities that 'only time will tell whether the current adaptive approach will be able to protect the Queensland environment from what the Queensland Government acknowledges are the "unknown and unintended impacts" of CSG production'. Uncertainties therefore remained not just with residents in host communities but also within the Queensland state's regulation of CSG projects-albeit in different forms and to varying levels of acceptability.

By focusing on these uncertainties, community members' conforming resistance brought forward more nuanced challenges wherein the epistemic and, ultimately, regulatory authority of gas companies and the Queensland state in relation to CSG developments' associated risks is at stake. Such challenges and their counter-claims are often articulated through debates over the status of scientific research in relation to environmental and health risks-discourses that tie into appealing and powerful tropes of environmental degradation and human rights violations. However, these scientific debates can mask wider conflicts around crucial sociocultural aspects of resource extraction, including envisioned development futures and the relationship between the state, its citizens and multinational companies (Ballard and Banks 2003: 299; Espig 2018: 222-6). The political dimension and critical role of the Queensland state's 'go grow' attitude in this regard is apparent in comparison to other Australian states that followed a 'go slow' approach or have banned onshore unconventional gas developments altogether (Cronshaw and Quentin Grafton 2016; de Rijke 2018). From this vantage point, the next section outlines Western Downs residents' experiences of CSG risk debates with the aim of exploring the wider sociocultural aspects of resource developments and the role of the state within them. 


\section{An Arms Race of Sorts: Outpaced and Beyond Capacity}

The scale and pace of the CSG boom in the Western Downs played a major role in the narratives of my interlocutors. The authors of an industry review note that companies got 'swept up in a groundswell of enthusiasm and a "get it done at any cost" mentality', resulting in 'an "arms race" of sorts in assuring access to scarce resources' (Reid and Cann 2016: 4, 10). The pace and manner of development created a range of social impacts, from labour shortages to housing pressure, and gave rise to questions around CSG developments' potential impacts and associated uncertainties. These were not merely issues for local community members. Similar views were also expressed by urban-based industry professionals, consultants and researchers who, for instance, discussed the inexperience of some government departments and companies with large-scale unconventional gas developments. Many of these interlocutors were critical of CSG projects' initially fast pace:

When this whole tsunami started in 2010 nobody, nobody, not even the lawyers, had any experience in what was going to happen and what the impacts were. Yet we are supposed to work out this agreement [with CSG companies] right at the start ... it has been a real problem. (Female landholder and CSG-specific regional NGO representative, Senate hearing, Brisbane, 27 July 2015)

That's the nightmare about it, it's so fast and that's why they're pushing so hard. (Female landholder with nearby CSG infrastructure, interview, June 2015)

It's the first time it's been done on this scale. ... It was a bit of a race. Everyone wanted to be first. I speak for the CEOs of the companies, they all wanted to get in before the rules changed. Because it was very favourable early on ... We described it as the big steam roller ... If we don't move fast enough to stay ahead of it, it's just going to get you ... Once they had invested the money, there was no stopping the project. (Male industry-based senior hydrologist, interview, April 2015)

The responsibility for this rapid development lies largely with pro-development Queensland state governments that approved CSG projects and the gas companies that pushed them. The local council in the Western Downs was frequently bypassed (de Rijke 2013b: 15), which is unsurprising given that legislative barriers usually prevent 
Australia's local governments from taking more active roles in planning for major resource projects (Barclay et al. 2012). ${ }^{6}$ Around the time of the CSG resource boom, Barclay and co-authors (2012: 19) also noted 'a widespread perception that [Australian] state governments are failing to provide adequate resources to assist local governments in meeting the challenges created by rapid expansion in the resources sector'. However, state governments themselves may lack these resources when confronted with multiple large-scale natural resource developments. Some observers have therefore linked the rapid expansion of Queensland's CSG projects to a then already decade-old Australian resource boom that saw governments approve mineral and hydrocarbon developments at a scale and pace that challenged - and possibly exceeded - their own regulatory capacity and policies (Cleary 2011; Taylor and Hunter 2019; cf. Eriksen's 2016, 2018 notion of 'runaway growth processes' more broadly).

Following this rush, many questioned whether the industry and Queensland state departments were able to understand and manage CSG's potential impacts. According to some observers, this was partly due to a long decline of departments' internal capacities and the transitioning of expert public servants into the CSG industry. Such transitions were prompted by departmental staff reductions and financial incentives from better paying industry positions. Concerns thus often involved departments lacking staff and time to adequately assess projects' Environmental Impact Statements (EISs) and an imbalance of scientific research capacities skewed towards CSG companies (see also Holcombe, Chapter 7, this volume). A female public servant in charge of the assessment of one CSG project noted in an informal conversation how she and colleagues often had to 'take things at face value from proponents', which was 'difficult, especially when you don't believe them'. They thus 'felt constantly behind' in their assessment (February 2016). The public servant's comments signal a disparity between the department's entrusted responsibilities of regulatory oversight and actual ability to fulfil this responsibility, perhaps primarily in terms of the

6 Barclay and co-authors (2012: 15) highlight that Australian local governments primarily perform two functions: a service/management role (delivery of local services and collection of taxes) and a political/representative role (represent the interests of their constituents at the local level). In terms of statutory authority over mineral and hydrocarbon developments, the Department of Infrastructure, Local Government and Planning (QSG 2017: 3) clarifies that 'resource development proposals are not assessed against local government planning schemes or by local governments'. 
department's capacity rather than its willingness to perform these tasks (see also Skrzypek, Chapter 2, this volume). This perspective resonates with the concerns of other industry and government professionals:

It outpaced organisations that were far better equipped to deal with that sort of thing than any individual in the community ... We [the regional mayor and I] were talking about how many EISs they were having to deal with ... He was talking about five or six at any one time, not just five or six in total ... And they were worried at the time that they didn't have the capability or the capacity to do it full justice. We got one delivered here ... It was 12,000 pages. It was ridiculous. Now tell me of anybody around, particularly regional areas, outside of the highly specialised knowledge of a university or government agency that can even begin to interpret that. (Male regional natural resource manager, interview, April 2015)

Everybody from our side, from the environmental professional side, were saying 'there's just not enough people to do this job properly for all of these sites' ... The three companies would have had the most water experts in any one room at any one time for any government or industry ... Government had eight technical people and two managers in all of Queensland ... In perspective, we had 32 technical people ... So, we were essentially educating the government on what we were going to do with that water. (Male industry-based senior hydrologist, interview, April 2015)

Such limitations are not unique to the context of CSG projects in the Western Downs. State and provincial governments frequently struggle to effectively assess and manage impacts of large-scale resource developments (Measham et al. 2016: 107-8). However, a discrepancy between the state's sovereign power to approve extractive projects and its ability to oversee and responsibly regulate the sector can be problematic, particularly for local residents who are caught up in this disparity.

Legitimate doubts were therefore expressed regarding the initially low levels of scientific certainty of the CSG industry's risks and the ability of various departments to adequately monitor developments, including potentially unknown side effects. Scientific uncertainty was accompanied by normative uncertainties regarding the efficacy of regulatory processes and the state's capacity to enforce regulation. Against a background of rushed projects, these uncertainties became a point of contestation, with more prior scientific research or a slower pace of development being viable 
alternative pathways. The rapid progress of CSG projects and associated unknowns were not accepted by a number of actors who argued that many uncertainties could, and should, have been avoided (see more broadly Wehling 2006: 127-31; Beck and Wehling 2012: 40). Citizens' trust in the Queensland state responsibly facilitating CSG developments was therefore, among other things, contingent upon its perceived regulatory capacities. Unsurprisingly, some local community members who were confronted with uncertainties around potential impacts on their future agricultural livelihoods or health demanded answers to open questions. However, the responses they received were often unsatisfactory.

\section{No Straight Answer: The Encounter of Organised Irresponsibility}

In searching for certainty, a number of interlocutors noted that the responses they received to their questions from government or company staff were often limited to their area of expertise and assigned responsibility. Some were advised to instead contact another department or unit. As a result, these community members felt that they were sent around in circles and were not satisfied with what they regarded as specific questions remaining essentially unanswered. A sense of frustration was frequently palpable:

The response that we got to a seven-page letter detailing all of the issues ... was embarrassing, particularly with regard to things like very specific information we've given them about actual harm ... It was three pages versus my seven pages. It's this: at arm's length, no actual depth, no investigation ... Please [government department] tell us what happened, please advise us? They have told us nothing ... And it's in free fall, hands off the wheel, choose your own adventure. (Female landholder with nearby CSG infrastructure, property tour, April 2015)

And you ask them [a government department] questions about health impacts of CSG and they ask you a question for the answer. (Male regional town resident and church minister, interview May 2015)

Who is taking responsibility for collating all this stuff? ... Somebody needs to be responsible ... So, there are four or five government departments in there conflicting and 
belting each other up ... Half the government agencies have skin in the game in this space and no one is ultimately saying or doing anything about the problems ... What he [local grazier] is concerned about is the way the department has written that has made it so ambiguous, so farcical that it doesn't make any sense. Hence, he gets cranky because he doesn't understand it-none of us understand it because the letter is a pile of rubbish ... And how poles apart are Natural Resources and Mines and Queensland Health? ... So, then you throw in the middle of that Environment and Heritage Protection, then Agriculture ... to muddy the waters. (Male state politician, interview, April 2015)

For citizens seeking clear answers to questions regarding risks associated with CSG developments, these perceptions of Queensland state departments' lack of responsibility can increase uncertainties, lead to mistrust-itself a form of moral uncertainty-and alienate them from government structures (Wynne 1996: 42; Gill 2011). ${ }^{7}$ The above observations were echoed in a subsequent review of two Queensland departments with CSG-specific regulatory responsibilities and one entity with a legislated oversight role to the state's regulatory framework (QSG 2020).

From the perspective of concerned local community members, I interpret these findings by borrowing from sociologist Ulrich Beck who argues that in contemporary ecological risk debates ' $[\mathrm{r}]$ esponsibilities can indeed be assigned but they are spread out over several social subsystems' (Beck 2009: 193). This, he contends, leads to 'responsibility as impunity or: organized irresponsibility' wherein 'no individual or institution seems to be held specifically accountable for anything' (ibid.: 194, original emphasis; also Douglas and Wildavsky 1982: 79-82; Dwyer and Minnegal 2006: 10-2 and 20). This organised irresponsibility stands in contrast to the Queensland state's authority to approve and regulate resource developments. As a result, concerned members of host communities and the wider public who submitted complaints were left searching for definite answers and advice. They questioned the perceived lack of government oversight, which caused problems of unclear responsibilities and ultimately accountability. This led to further normative uncertainties regarding the role of state departments and other entities with legislated oversight (e.g. the GasFields Commission Queensland). It is in these

7 Cf. Auyero and Swistun's (2008: 369-71) notion of the social production of toxic uncertainty through, among other aspects, state officials' 'labor of confusion and state (mis)interventions'. See also Stilgoe (2007). 
liminal spaces, in between state presence and absence, where concerned community members who experience the rapid environmental and social transformations of a natural resource boom can encounter what Bainton and Skrzypek (Chapter 1, this volume) describe as the absent presence of the state. Here, everyday perceptions and practices, such as moving in circles between state departments, are important modes through which the state comes into being for concerned community members, mainly in the form of a heightened sense of its perceived failure to fulfil regulatory responsibilities (Sharma and Gupta 2005).

Considering the difficulties in forecasting impacts and projects' rushed progress, it is debatable whether definite answers could have been given to some of the questions raised by community members. ${ }^{8}$ Several industry professionals also emphasised the indeterminacies of CSG developments; for example, exact infrastructure locations or the ultimate numbers of wells in a field can often not be determined at the onset but are influenced by outcomes of ongoing extraction. Other interlocutors appeared somewhat satisfied with the information and conflict resolution processes offered by, for instance, the Queensland Government's CSG Compliance Unit. However, for many concerned community members, perceived irresponsibilities have resulted in a diminishing trust in the relevant governing structures (Lloyd et al. 2013; Gillespie et al. 2016). Some addressed the perceived absence of adequate oversight by either individually or collectively trying to scrutinise the industry and government. One landholder argued at a community meeting that CSG companies 'need to be made accountable. No one else out here is going to do that. It's up to us, the community, to do that, because there simply is no other overseer. There should be, but there isn't' (April 2015). A grazier and representative of a regional CSG-focused NGO similarly criticised the Queensland Government's Mineral and Energy Resources (Common Provision) Bill 2014 that temporarily restricted public objection rights to extractive projects by noting, 'We are the watchdogs for our democracy and don't let any politician tell you otherwise' (group discussion April 2015; see Espig and de Rijke 2018: 220-1).

8 In contexts of uncertainties and unknowns one might also not be willing to accept responsibility and refuse to give a straight answer. Povinelli's (1993: 685) analysis of the language of indeterminacy in an Australian Aboriginal community is insightful, particularly 'the relationship among knowledgeclaims, responsibility-culpability, and authority-status'. See also Gluckman (1972). 
Such a felt absence of government oversight can, in tandem with scientific uncertainties and a heightened sense of mistrust, lead to insecurities and frustration among local residents and landholders (Checker 2007; Beck 2009: 45-6). Some citizens and groups find themselves compelled to scrutinise the CSG industry themselves, which can create privatised forms of risk management (Jasanoff 2002: 375; Rose 2005: 158; Pyysiäinen et al. 2017). However, whether scrutiny can be exercised effectively in light of the techno-scientific and ecological complexities of CSG developments, and by whom, must be critically evaluated.

\section{Displacement, Responsibilisation and the Absent State}

The two preceding sections portray instances of an absent presence of the state, within which securing investments and economic benefits might be perceived by some as taking priority over community members' risk concerns. A variety of local and 'outside' interlocutors (cf. Espig and de Rijke 2018: 220-1) attempted to assume regulatory responsibilities by challenging gas companies and the Queensland state's adaptive management regime through the means available to them, from conforming resistance to outright civil disobedience. Many concerned residents were not satisfied with a circular transfer of responsibility between companies and impotent state departments through, for instance, reference to regulation-compliant behaviour. As a female attendee at a company-organised gas facility tour emphasised in her response to a CSG company representative, '[p]eople want answers and details. It's not going to help to say, "We comply" (July 2015). Such 'discourses of compliance' (Stilgoe 2005) can turn questions concerning unknowns into issues of measurement and compliance to set guidelines. These guidelines represent what is known about particular hazards and politically acceptable regulation at a given moment in time. Discourses that stress compliance with such guidelines might then create cognitive and social authority, but they can potentially obscure uncertainties and demarcate unknowns from further consideration. Reference to compliance also allows regulatory agencies to manage contested issues solely in scientific terms, which excludes non-scientific forms of knowledge from decisionmaking processes. Actors whose concerns remain unanswered, or are not even acknowledged, might consequently feel prompted to challenge 
the foundations of regulatory processes. The efficacy of discourses of compliance can thus be limited, especially when the underlying adequacy of guidelines is questioned (Stilgoe 2005, 2007).

Similar problems emerge when Queensland state departments passed on complaints about misconduct or impacts to companies for investigation. As a regional town resident explained:

It's not just a blind mistrust. The mistrust is because we've seen it over and over again: here's my complaint and I'm giving it to [government departments]. They take it and go to bloody [company name] and say, 'Here's this complaint'. So, they hand it over and [company name] write their report, hand it back to them and then they take it back to the landowner saying, 'There's the report, everything is fine' ... Self-regulation, self-reportingit doesn't work. (Opposing female town resident, interview, May 2015)

Such instances constitute what Trouillot (2003: 90) describes as a displacement of state functions from governments to, in this case, private transnational companies (also Sharma and Gupta 2005: 21-2). In the context of the extractive industries, examples of such practices include the delegation of regulatory responsibilities to resource companies and their self-regulation through corporate social responsibility or voluntary industry initiatives (Brereton 2003; Dashwood 2012; Owen and Kemp 2017; also Bainton and Skrzypek, Chapter 1, this volume). One implication is that, within host communities, residents' uncertainties and distrust can increase when compliance is associated with irresponsibility among state departments as well as adaptive management regimes being reliant on company expertise and self-regulation. Unsurprisingly, concerned Western Downs residents and their allies in the wider public often contested the scientific foundation of state regulations and company conduct.

The resources they have at their disposal to put pressure on CSG companies and the government vary, though. The relatively wealthy and politically well-represented farmers in the Western Downs' eastern cotton growing area mounted a formidable challenge by investing considerable amounts of money into independent hydrological studies that demonstrated the limited understanding of interconnectivity between agriculturally used aquifers and those targeted by CSG companies. This kept proposed developments off prime agricultural land and prompted lengthy research 
trials. Small-scale residential landholders further west, on the other hand, found themselves in the midst of multiple gas fields. Among those living on so-called 'lifestyle blocks', located on agriculturally less valuable land, are members of vulnerable and lower income groups who could hardly afford a few hundred dollars to have water in their tanks or dams tested (Makki 2015; Makki and van Vuuren 2016). ${ }^{9}$ The effectiveness of their challenges has therefore generally been lower than that of other groups in the Western Downs. I interpret this as the result of an interplay between multiple, unequally distributed financial, social and political 'capitals' (Bourdieu 1986; Everingham et al. 2014, 2015; QSG 2020). Residents' ability to mobilise such capitals influences experiences of regional change and the uncertainties associated with CSG developments by allowing some to develop a sense of agency and beneficial engagement with the industry. It seems that actors and groups with greater levels of pre-existing capitals tend to have benefited to a higher degree from CSG projects and were able to negotiate better compensation agreements, have a stronger say in where infrastructure is located on their property, or could avoid certain impacts (Measham et al. 2016: 107-8). So, while concerned Western Downs residents from a range of socioeconomic and cultural backgrounds challenged companies and the Queensland state, the outcomes they were able to achieve varied. This led to different experiences of CSG developments and of their encounters with the state.

The observation that individual community members become selfreliant on their own capabilities and capitals to secure their welfare is consistent with a broader neoliberal shift that has occurred in Australia's agricultural regions since the 1970s. This policy shift includes the private responsibilisation of farmers as individual, economically independent entrepreneurs and responsibility-taking agents (Pyysiäinen et al. 2017). In the context of Pennsylvania's shale gas projects (another form of unconventional natural gas), Malin (2014) critiqued similar developments as imposing a form of neoliberal individualisation and logic onto farmers. In debates over the complex environmental and health risks associated with CSG extraction, such an individualisation creates new demands and responsibilities for concerned community members. For some, profound limitations emerge if, for example, they are unable to conduct

9 There are some 2,100 rural subdivisions, or 'lifestyle blocks', between Tara and Chinchilla, typically ranging from 13-40ha. Established since the 1980 s on poor agricultural land, these subdivisions are primarily affordable residential properties. Here, the civil disobedience movement against CSG developments began (see Makki 2015). 
or afford scientific testing for suspected air pollution from nearby CSG activities. These residents and interested outsiders often face higher levels of uncertainty and what risk scholars describe as a decline in ontological security. As Beck (2009: 45-6 and 195, original emphasis) emphasises within his risk society thesis:

a dramatic decline of ontological security now confronts lifeworlds, even in the peaceful corners of the earth. The three pillars of security are crumbling-the state, science and the economy ... and are naming the 'self-conscious citizen' as their legal heir. But how are individuals supposed to accomplish what state, sciences and economic enterprises are unable to achieve? ... The brutal fact of ontological insecurity always has an ultimate addressee: ... the individual. Whatever propels risk and makes it incalculable ... shifts the ultimate decision-making responsibility onto the individuals, who are ultimately left to their own devices with their partial and biased knowledge, with undecidability and multiple layers of uncertainty.

Similarly, Giddens (1991: 131, original emphasis) notes 'the inevitability of living with dangers which are remote from the control not only of individuals, but also of large organisations, including states'. This uncontrollability can lead to a 'sense of dread which is the antithesis of basic trust' (ibid.: 133). Notwithstanding the problematic generalising tendencies of these grand theoretical claims (see Dwyer and Minnegal 2006), Beck and Giddens highlight an often underappreciated aspect of what it might mean to live with the insecurities of complex 'manufactured risks'; that is, those predominantly created by the increasing scale of humans' application of techno-scientific capabilities. Negative psychological, sociocultural and political ramifications of risk and uncertainty can be observed especially within contexts where citizens perceive a disparity between the regulatory mandate of the state and its capacity to fulfil those responsibilities.

However, a retreat of the state and corresponding privatisation of risk management might also create opportunities for the reconfiguration of the power relationships between the state and its subjects. Rose (2005: 159) contends that the active citizens of 'advanced' liberal democracies can create new demands and challenges towards those in positions of authority: 
Here we can witness the 'reversibility' of relations of authoritywhat starts off as a norm to be implanted into citizens can be repossessed as a demand which citizens can make of authorities. Individuals are to become 'experts of themselves', to adopt an educated and knowledgeable relation of self-care in respect of their bodies, their minds, their forms of conduct and that of the members of their own families.

Such challenges cannot only be established in relation to the private self but also in terms of wider societal debates, such as within environmental risk controversies. As indicated above, engaged landholders who could mobilise their various capitals effectively were able to create significant obstacles for gas projects. In the case of CSG developments in the adjacent state of New South Wales, the combination of local resistance and a national anti-gas movement was partly responsible for prompting the state government to even declare a moratorium on unconventional gas developments (Cronshaw and Quentin Grafton 2016; de Rijke 2018). ${ }^{10}$

These cases indicate that driven individuals, well-organised groups and international networks of interest can indeed challenge states and extractive companies in response to what they experience as an absence of adequate government regulation and a subsequent privatisation of risk management. However, this does not answer the questions of whether those who can bring forth such challenges should have to assume this responsibility, what eventually constitutes successful challenges, and whether their claims can be articulated in time before rapidly progressing projects create realities on the ground that foreclose alternative development pathways. It is thus possible that one element of conforming resistance is a 'neoliberal "unloading" of public services onto empowered and "responsibilized" selves and communities who ... are thereby made complicit in the contemporary workings of power and governance'

10 Similar challenges can also be found in other extractive sectors. Stuart Kirsch $(2014,2018)$, for instance, describes how Yonggom community members and a network of international NGOs and sympathisers were able to successfully sue BHP in Australia over the environmental damages caused by riverine tailings disposal at their Ok Tedi copper and gold mine in Papua New Guinea. 
(Sharma and Gupta 2005: 21). ${ }^{11}$ Local community members who are already vulnerable, marginalised or in socioeconomically weaker positions all too often find themselves on the downside of the accompanying individualisation of risk. The responsibilisation of the self can, in this sense, lead to the inconspicuous (re)production of social inequalities and unequal risk positions. As Jasanoff (2015: 17) notes, '[i]f networks diffuse responsibility, they can also depoliticize power by making its actions opaque or invisible'. With limited means to respond to what community members regard as the transfer of responsibility for their environments and health, their options are restricted to either moving away—as a number of interlocutors did-or to protest with their physical bodies against CSG development as a last resort. In any way, challenging regulatory institutions and those in positions of power and authority never occurs without significant personal investment, effort and sacrifice. Many individuals and groups can therefore only temporarily resist the pressures that arise from a perceived absence of the state.

\section{Conclusion}

In this chapter, I discussed concerned host community members' experiences of the state regarding CSG developments in the Western Downs. This ethnographic account should not be read as a thorough analysis of the Queensland state's regulatory instruments and agencies. Neither does it address the experiences of residents supporting CSG development or those who were not concerned about associated risks (see Espig 2018: 141-66). Here, I focused specifically on community members for whom CSG projects posed a clear and present threat. While I do not suggest that the Queensland state should be considered as 'failed' in this regard-especially in comparison to other jurisdictions discussed in this volume and elsewhere-my aim was to demonstrate that marginal

11 Pyysiäinen and co-authors (2017) present a critical analysis of Australian farmers' reactions to neoliberal 'responsibilisation' that provides complementary insights into individuals' experiences of the state. Contrary to neoliberal theory, most farmers they surveyed did see the causal explanations for their situation in external structural factors, such as government policies or macroeconomic conditions. As neoliberal theorists argue, however, a majority reacted with an internally-oriented response, or 'psychological reactance', wherein they took on the responsibility of actively regaining control and changing their circumstances, while only a smaller group demanded structural changes. These observations are insightful for the presented ethnographic findings: one might interpret individuals' or groups' attempts to regain control and 'hold the industry accountable' as an internalisation of responsibility in reaction to a perceived absence of satisfactory state regulation. 
spaces of partial state presence do not only emerge in relatively recent postcolonial, new or 'weak' states (Das and Poole 2004: 4). Instead, a dialectic of presence and absence might also manifest within highly industrialised and, at first sight, well-regulated democratic states. The experiences of concerned community members in the Western Downs highlight that a perceived lack of regulatory oversight can become all too present in their daily encounters with the state, which shows that 'phenomena may have a powerful presence in people's lives precisely because of their absence' (Bille et al. 2010: 4, original emphasis). This dialectic of presence and absence is part of an ongoing reconfiguration of the relationships between the Queensland state, its subjects and private, multinational gas companies. In this sense, CSG risk debates do not just concern ecological hazards in a narrow sense but constitute a broader commentary on the social world (Espig 2018: 222-6) and the sociocultural transformations associated with large-scale natural resource developments.

While Ballard and Banks (2003) emphasise that, as part of these reconfigurations, local communities encounter the full power of the state's sovereign claims to natural resources, they also recognise the countervailing powers communities can mobilise. The outlined cases of resistance to CSG developments detail how states and private companies can face formidable challenges from local community members. This has critical implications for the relationship between citizens and the extractive industries. Writing about mining contexts, Kirsch (2014: 32-3) suggests that states' limited presence, especially in rural areas, brings extractive companies into closer contact with surrounding communities. As companies assume state responsibilities, however, they might also be held accountable for shortcomings of the state more broadly (also Owen and Kemp 2017: 187). This means that:

The mining industry can no longer assume that the state is its only negotiating partner or that rural or indigenous communities lack the resources or capacity to challenge their operations, whether by forging international alliances with NGOs and other partners, through legal action in the countries in which the corporations are based, or by force-albeit at a terrible cost. (Kirsch 2014: 232)

My ethnographic account of Queensland's CSG developments supports this assessment, with the important caveat that the 'reversibility of relations of authority' (Rose 2005: 159) is contingent upon community members' various capitals and capacities that enable or constrain them 
from formulating challenges to the state or private companies. These capitals may be considerably higher for many citizens in the Western Downs, compared to other communities discussed in this volume. Across these diverse contexts, however, it is important to pay attention to social inequalities, power imbalances and unequal risk positions that can be (re)produced in local responses to a limited state presence.

In outlining the dialectic of presence and absence within CSG risk debates, I discussed the encounters between a subset of host community members and the Queensland state. The ethnographic account of their experiences points towards the roles citizens might assume within resource development contexts that are seemingly driven by neo- or advanced liberal policies. Considering the ecological and techno-scientific complexities of CSG developments, I echo Beck's (2009: 45-6 and 195) concern over whether individual citizens can close the gap left by, at least partially, absent states. This is, of course, not to suggest that all citizens perceive such a gap or are equally affected by it, nor to follow Beck's (ibid.) gloomy outlook that they are 'ultimately left to their own devices'. Nonetheless, it is important to critically consider what happens when, for some, states appear to fail in their task to safeguard against risks and harm, especially against a backdrop of an uneven distribution of different forms of uncertainty, risk and sociocultural as well as economic capitals. What, then, are the responsibilities and accountabilities of state departments, community members, private companies, NGOs, universities or research institutes in regard to the risks of extractive projects such as CSG developments? Drawing out some of the challenges local community members experienced around the ongoing reconfiguration of the public and private within the dialectic of the Queensland state's presence and absence can contribute towards addressing this pressing question.

\section{References}

AFG (Australian Federal Government), 2018. 'Australian Energy Resources Assessment: Gas.' Canberra: Geoscience Australia.

Auyero, J. and D. Swistun, 2008. 'The Social Production of Toxic Uncertainty.' American Sociological Review 73: 357-379. doi.org/10.1177/0003122408 07300301 
Bainton, N. and J.R. Owen, 2018. 'Zones of Entanglement: Researching Mining Arenas in Melanesia and Beyond.' Extractive Industries and Society 6: 767-774. doi.org/10.1016/j.exis.2018.08.012

Ballard, C. and G. Banks, 2003. 'Resources Wars: The Anthropology of Mining.' Annual Review of Anthropology 32: 297-313. doi.org/10.1146/annurev.anthro. 32.061002 .093116

Barclay, M.A., J. Everingham, L. Cheshire, D. Brereton, C. Pattenden and G. Lawrence, 2012. 'Local Government, Mining Companies and Resource Development in Regional Australia: Meeting the Governance Challenge.' St Lucia: University of Queensland, Centre for Social Responsibility in Mining.

Beck, U., 2009. World at Risk. Cambridge and Malden: Polity Press.

Beck, U. and P. Wehling, 2012. 'The Politics of Non-Knowing: An Emerging Area of Social and Political Conflict in Reflexive Modernity.' In F.D. Rubio and P. Baert (eds), The Politics of Knowledge. London: Routledge. doi.org/ $10.4324 / 9780203877746$

Bille, M., F. Hastrup and T.F. Sørensen (eds), 2010. An Anthropology of Absence: Materializations of Transcendence and Loss. New York: Springer. doi.org/ 10.1007/978-1-4419-5529-6

Bourdieu, P., 1986. 'The Forms of Capital.' In J. Richardson (ed.), Handbook of Theory and Research for the Sociology of Education. Westport (CT): Greenwood Press.

Brereton, D., 2003. 'Self-Regulation of Environmental and Social Performance in the Australian Mining Industry.' Environmental and Planning Law Journal 20: $261-274$.

Checker, M., 2007. “'But I Know It's True”: Environmental Risk Assessment, Justice, and Anthropology.' Human Organization 66: 112-124. doi.org/ 10.17730/humo.66.2.1582262175731728

Cleary, P., 2011. Too Much Luck: The Mining Boom and Australia's Future. Collingwood (Vic.): Black Inc.

Cronshaw, I. and R. Quentin Grafton, 2016. 'A Tale of Two States: Development and Regulation of Coal Bed Methane Extraction in Queensland and New South Wales, Australia.' Resources Policy 50: 253-263. doi.org/10.1016/ j.resourpol.2016.10.007

Das, V. and D. Poole (eds), 2004. Anthropology in the Margins of the State. Oxford and New York: Oxford University Press. 
Dashwood, H., 2012. The Rise of Global Corporate Social Responsibility: Mining and the Spread of Global Norms. Cambridge: Cambridge University Press. doi.org/10.1017/CBO9781139058933

De Rijke, K., 2013a. 'The Agri-Gas Fields of Australia: Black Soil, Food, and Unconventional Gas.' Culture, Agriculture, Food and Environment, 35(1): 41-53. doi.org/10.1111/cuag. 12004

- 2013b. 'Hydraulically Fractured: Unconventional Gas and Anthropology.' Anthropology Today 29(2): 15-17. doi.org/10.1111/14678322.12017

2018. 'Drilling Down Comparatively: Resource Histories, Subterranean Unconventional Gas and Diverging Social Responses in Two Australian Regions.' In R.J. Pijpers and T.H. Eriksen (eds), Mining Encounters: Extractive industries in an overheated world. London: Pluto Press. doi.org/10.2307/ j.ctv893jxv. 10

Douglas, M. and A. Wildavsky, 1982. Risk and Culture. Berkeley: University of California Press.

Dwyer, P.D. and M. Minnegal, 2006. 'The Good, the Bad and the Ugly: Risk, Uncertainty and Decision-Making by Victorian Fishers.' Journal of Political Ecology 13: 1-23. doi.org/10.2458/v13i1.21675

Edwards, G., 2006. 'Is There a Drop to Drink? An Issue Paper on the Management of Water Co-Produced with Coal Seam Gas.' Brisbane: Queensland Department of Mines and Energy.

Eriksen, T.H., 2016. Overheating: An Anthropology of Accelerated Change. London: Pluto Press.

2018. Boomtown: Runaway Globalisation on the Queensland Coast. London: Pluto Press. doi.org/10.2307/j.ctv3mt8xn

Espig, M., 2018. Getting the Science Right: Queensland's Coal Seam Gas Development and the Engagement with Knowledge, Uncertainty and Environmental Risks. St Lucia: University of Queensland ( $\mathrm{PhD}$ thesis). doi.org/10.14264/uql.2018.345

Espig, M. and K. de Rijke, 2016. 'Unconventional Gas Developments and the Politics of Risk and Knowledge in Australia.' Energy Research and Social Science 20: 82-90. doi.org/10.1016/j.erss.2016.06.001

2018. 'Energy, Anthropology and Ethnography: On the Challenges of Studying Unconventional Gas Developments in Australia.' Energy Research and Social Science 45: 214-223. doi.org/10.1016/j.erss.2018.05.004 
Everingham, J.A., N. Collins, W. Rifkin, D. Rodrigues, T. Baumgartl, J. Cavaye and S. Vink, 2014. 'How Farmers, Graziers, Miners, and Gas-Industry Personnel See Their Potential for Coexistence in Rural Queensland.' SPE Economics and Management 6(3): 122-130. doi.org/10.2118/167016-PA

Everingham, J.A., V. Devenin and N. Collins, 2015. “'The Beast Doesn't Stop”: The Resource Boom and Changes in the Social Space of the Darling Downs.' Rural Society 24: 42-64. doi.org/10.1080/10371656.2014.1001480

GCQ (GasFields Commission Queensland), 2018. 'Queensland's Petroleum and Gas Industry Snapshot.' Brisbane: GCQ.

Giddens, A., 1991. The Consequences of Modernity. Cambridge: Polity Press.

Gill, F., 2011. 'Responsible Agents: Responsibility and the Changing Relationship Between Farmers and the State.' Rural Society 20: 128-141. doi.org/10.5172/ rsj.20.2.128

Gillespie, N., C. Bond, V. Downs and J. Staggs, 2016. 'Stakeholder Trust in the Queensland CSG Industry.' Australia Petroleum Production and Exploitation Journal 56: 239-246. doi.org/10.1071/AJ15018

Gluckman, M. (ed.), 1972. The Allocation of Responsibility. Manchester: Manchester University Press.

Hepburn, S., 2015. Mining and Energy Law. Melbourne: Cambridge University Press. doi.org/10.1017/CBO9781107480025

Jasanoff, S., 2002. 'Citizens at Risk: Cultures of Modernity in the US and EU.' Science as Culture 11: 363-380. doi.org/10.1080/0950543022000005087

2015. 'Future Imperfect: Science, Technology, and the Imaginations of Modernity.' In S. Jasanoff and S.H. Kim (eds), Dreamscapes of Modernity: Sociotechnical Imaginaries and the Fabrication of Power. Chicago: University of Chicago Press. doi.org/10.7208/chicago/9780226276663.001.0001

Kirsch, S., 2014. Mining Capitalism: The Relationship between Corporations and their Critics. Oakland: University of California Press.

- 2018. Engaged Anthropology: Politics beyond the Text. Oakland: University of California Press.

Lloyd, D.J., H. Luke and W.E. Boyd, 2013. 'Community Perspectives of Natural Resource Extraction: Coal-Seam Gas Mining and Social Identity in Eastern Australia.' Coolabah 10: 144-164. 
Makki, M., 2015. Coal Seam Gas Development and Community Conflict: A Comparative Study of Community Responses to Coal Seam Gas Development in Chinchilla and Tara, Queensland. St Lucia: University of Queensland (PhD thesis). doi.org/10.14264/uql.2015.1105

Makki, M. and K. van Vuuren, 2016. 'Place, Identity and Stigma: Blocks and the "Blockies” of Tara, Queensland, Australia.' GeoJournal 82(6): 1-15. doi.org/ 10.1007/s10708-016-9730-2

Malin, S., 2014. 'There's No Real Choice But to Sign: Neoliberalization and Normalization of Hydraulic Fracturing on Pennsylvania Farmland.' Journal of Environmental Studies and Sciences 4: 17-27. doi.org/10.1007/s13412-0130115-2

Measham, T.G., D.A. Fleming and H. Schandl, 2016. 'A Conceptual Model of the Socioeconomic Impacts of Unconventional Fossil Fuel Extraction.' Global Environmental Change 36: 101-110. doi.org/10.1016/j.gloenvcha. 2015.12.002

Mercer, A., K. de Rijke and W. Dressler, 2014. 'Silences in the Boom: Coal Seam Gas, Neoliberalizing Discourse, and the Future of Regional Australia.' Journal of Political Ecology 21: 279-302. doi.org/10.2458/v21i1.21137

Ortner, S.B., 1995. 'Resistance and the Problem of Ethnographic Refusal.' Comparative Studies in Society and History 37: 173-193. doi.org/10.1017/ S0010417500019587

Owen, J.R. and D. Kemp, 2017. Extractive Relations: Countervailing Power and the Global Mining Industry. London: Routledge.

Povinelli, E.A., 1993. “"Might Be Something”: The Language of Indeterminacy in Australian Aboriginal Land Use.' Man 28: 679-704.

Pyysiäinen, J., D. Halpin and A. Guilfoyle, 2017. 'Neoliberal Governance and "Responsibilization" of Agents: Reassessing the Mechanisms of ResponsibilityShift in Neoliberal Discursive Environments.' Distinktion 18: 215-235. doi.org/10.1080/1600910X.2017.1331858

QSG (Queensland State Government), 2017. 'Mining and Extractive Resources.' Brisbane: Department of Infrastructure, Local Government and Planning. , 2020. 'Managing Coal Seam Gas Activities.' Brisbane: State Audit Office (Report 12: 2019-20).

Reid, S. and G. Cann, 2016. 'The Good, the Bad and the Ugly: The Changing Face of Australia's LNG Production.' Deloitte Australia. 
Rose, N., 2005. 'Governing “Advanced” Liberal Democracies.' In A. Sharma and A. Gupta (eds), The Anthropology of the State: A Reader. Oxford: Blackwell.

Sharma, A. and A. Gupta, 2005. 'Introduction: Rethinking Theories of the State in an Age of Globalization.' In A. Sharma and A. Gupta (eds), The Anthropology of the State: A Reader. Oxford: Blackwell.

Stilgoe, J., 2005. 'Controlling Mobile Phone Health Risks in the UK: A Fragile Discourse of Compliance.' Science and Public Policy 32: 55-64. doi.org/ $10.3152 / 147154305781779704$

_ 2007. 'The (Co-)Production of Public Uncertainty: UK Scientific Advice on Mobile Phone Health Risks.' Public Understanding of Science 16: 45-61. doi.org/10.1177/0963662506059262

Swayne, N., 2012. 'Regulating Coal Seam Gas in Queensland: Lessons in An Adaptive Environment Management Approach.' Environmental Planning and Law Journal 29: 163-185. eprints.qut.edu.au/49293/

Taylor, M. and T. Hunter, 2019. Agricultural Land Use and Natural Gas Extraction Conflicts: A Global Socio-Legal Perspective. Abingdon: Routledge. doi.org/10.4324/9780203702178

Trigger, D., 1997. 'Mining, Landscape and the Culture of Development Ideology in Australia.' Cultural Geographies 4: 161-180. doi.org/10.1177/ 147447409700400203

- 2000. 'Aboriginal Responses to Mining in Australia: Economic Aspirations, Cultural Revival, and the Politics of Indigenous Protest.' In P. Schweitzer, M. Biesele and R. Hitchcock (eds), Hunters and Gatherers in the Modern World: Conflict, Resistance, and Self-Determination. New York: Berghahn.

Trouillot, M.-R., 2003. Global Transformations: Anthropology and the Modern World. New York: Palgrave Macmillan. doi.org/10.1007/978-1-137-04144-9

Wehling, P., 2006. Im Schatten des Wissens? Perspektiven der Soziologie des Nichtwissens [In the Shadow of Knowledge? Perspectives of the Sociology of Nonknowledge]. Konstanz: UVK Verlagsgesellschaft mbH. doi.org/10.1007/ s11614-008-0007-y

Wynne, B., 1996. 'Misunderstood Misunderstandings: Social Identities and Public Uptake of Science.' In A. Irwin and B. Wynne (eds), Misunderstanding Science? The Public Reconstruction of Science and Technology. Cambridge: Cambridge University Press. doi.org/10.1017/CBO9780511563737 
This text is taken from The Absent Presence of the State in LargeScale Resource Extraction Projects, edited by Nicholas Bainton and Emilia E. Skrzypek, published 2021 by ANU Press, The Australian National University, Canberra, Australia.

doi.org/10.22459/AP.2021.06 